\title{
THE TEACHING OF POLITICAL SCIENCE AT OXFORD.
}

I HAVE been asked to give an account of the Teaching of Political and Social Science at Oxford, but in order to do this in a way which will not be unintelligible or misleading, it is necessary to give some preliminary explanations as to the relation between the Universities and the colleges, and as to the system of examination for the degree of B. A.

Professor Bryce has helped English readers to understand the relations between the States and the Nation in the American Union, by the analogy of the relation between the colleges and the University in Oxford and in Cambridge; and American readers may profitably reverse the analogy in order to understand roughly an academical system that exists in no country except England. The analogy is, indeed, only a rough one: the University existed before there were any colleges, and there are at the present time collegiate students whom we might perhaps compare to citizens of the United States living in a Territory. But just as every citizen of a State is also a citizen of the United States, so every member of a college is also a member of the University, and is thus subject to two different sets of institutions and rules. The University alone confers degrees and regulates the examinations for them. Instruction is, however, provided by both the University, through its "professors" and "readers" (the latter may be compared with the "extra-ordinary professors" of a German university), and by the colleges, through their tutors and lecturers. University lectures are open to all members of the University. College lectures are intended primarily for the members of particular col- 
leges, but of late years, through the system of combined lectures, college lectures have become in many cases as much "open" as University lectures. Most of the teaching, especially in some subjects, is done by the colleges. The University provides more of the instruction, relatively to what is done by the colleges, in natural science and in law than in other subjects.

As a general rule every undergraduate member of the University, except the "selected candidates" for the Indian Civil Service, who under present regulations cannot stay long enough, is supposed to be studying for the degree of B. A. But, as a matter of fact, the course of study is very different according as the student merely wishes to "pass" and obtain the degree, or aspires to "honours." The degree cannot be obtained in less than three years, and candidates who wish to take "honours" must not be of more than four years' standing when they come up for their final exanination. The higher degree of M. A. follows upon the B. A. simply "through the progress of time and the payment of fees." Every candidate must pass "responsions" before or soon after the outset of his academical career. This examination practically takes the place of an entrance examination, which as such does not exist in the University. Every college in Oxford requires intending students to pass an entrance (matriculation) examination, the standard of which is in some places considerably higher than "responsions." "Responsions" is an examination in school work (Latin and Greek, arithmetic, elementary geometry and algebra). The student must next pass or obtain "honours" in the "first public examination" (commonly known as "moderations"), an examination mainly in Greek and Latin, taken during the second academical year. The student who is going to take "honours jurisprudence" or "honours modern history" as his final school, may, under certain conditions, substitute for the classical moderations what is known as the "preliminary examination in jurisprudence." It is 
only in the "trial" or "second public examination" that subjects connected with political science come in. In this second public examination, a candidate may either take a "pass" in certain subjects, in which he has a limited range of choice, or he may seek to obtain "honours" (Ist, 2d, 3d, or 4th class) in one of the seven "honour schools." These are (r) Literce Humaniores (an examination mainly in certain Greek and Latin philosophical and historical books, and in kindred subjects), (2) Mathematics, (3) Natural Science, (4) Jurisprudence, (5) Modern History, (6) Theology, and (7) Oriental Studies. There is no special "school" of political and social science, but political philosophy (including political economy) is one of the subjects prescribed for the school of Litere Humaniores. The questions set on this subject form only half of one paper in the examination, being combined either with moral philosophy, or with a general paper on ancient history. Candidates may offer "political economy" or "theories of the State" with a special study of one or more treatises selected by them as "special subjects" in addition to the ordinary work; but special subjects do not flourish much in this school, the ordinary work being sufficiently varied and arduous for even the best students. In the school of jurisprudence (and in the kindred examination for the degree of B. C. L.), jurisprudence, English constitutional law, and international law form a part of the prescribed course. The school of jurisprudence, as already said, is one of the avenues to the degree of $B$. A. No one can obtain the degree of B. C. L. without having previously obtained the degree of $\mathrm{B}$. A. This degree he need not, however, have obtained through the school of jurisprudence. Certain books are "recommended" for special study. It should be added that this work in law is not in the strict sense a training for the legal profession, the qualifying examinations for which have in England no connection with the University examinations or degrees. In the school of modern history, political science and 
political economy are prescribed and constitute an important element in the examination. A knowledge of certain books is required, viz.: Aristotle's Politics (subject matter), part of Hobbes' Leviathan, Bluntschli's Theory of the State, Maine's Ancient Laws, and Mill's Political Economy. One of the subjects very commonly taken up for the final pass examination is the "Elements of Political Economy," read in Walker's Political Economy, and parts of Adam Smith. The candidate for the Indian Civil Service, studying at Oxford under the regulations in force (until I892), is occupied to a considerable extent with Indian law, Roman law, English law, jurisprudence and political economy, as well as with Oriental languages.'

In what precedes, we have described the place of political and social science in the Oxford examinations, and it now remains to show the actual provision for their instruction. This is given, as already explained, in part by the University and in part by the colleges. Annexed to this article will be found lecture lists of subjects connected with political and social science for I 890-I891 (extracted from its official lecture lists) which will serve as average

1 At present candidates, not above nineteen years of age, selected by government after a competitive examination, have to spend two years at an approved university, if they wish to receive the government allowance. By the regulations which will come into force in 1892 , no candidate must be under twenty-one years nor over twenty-four, and the subjects have been so altered that candidates who have studied for an "honour school " at Oxford will have a fair chance of success without further preparation. The time of special professional study after selection will, under the new system, be only one year, which will have to be devoted aimost entirely to the vernacular languages of the presidency to which the civilian is going, and to Indian laws. My friend, Mr. F. C. Montague, of Oriel College (the editor of Bentham's Fragment on Government), who has had much to do with the instruction of Indian civilian students in Oxford, summarizes the intentions of the present and of the future systems somewhat as follows: "The present system is a good general school education, followed by two years of professional education, obtained in the intellectual atmosphere of Universities, where general rather than professional education is the rule; the future system is intended to be the best University education with a minimum of professional training." I have thought it worth while to refer to the Indian Civil Service because it offers the only example in Great Britain of an attempt to regulate systematically the preparation for an administrative career. 
specimens. As there is no special school of political science there is no regular course in the subject, and some departments of it are often not represented on the lecture lists at all. The professors, readers, and lecturers in the faculty of law deal largely with political science; and the well-known names of Professors Dicey, Holland, Bryce, Sir F. Pollock, Sir William Anson, Sir William Markby, are all to be found in the lecture lists of the school of jurisprudence. There is a professorship of political economy in the University, recently vacant by the death of Professor Thorold Rogers, and now filled by the election of W. F. Y. Edgeworth. Lectures on political science, political economy, and economic history are given also by college tutors and lecturers in connection with the modern history school; and lectures on political philosophy (which does not differ much, if at all from political science, except in name) by college tutors and lecturers in connection with the school of litere humaniores. The professor of moral philosophy, Prof. W. Wallace, who succeeded the late T. H. Green, occasionally lectures on social institutions or some such subject as a part of his course on ethics. It must be remembered that the giving of a formal course of lectures represents only a small part of a college tutor's teaching work, and that some professors are also college tutors.

The University prescribes or recommends certain textbooks. Lectures are to a great extent supplementary to the study of these. Work which corresponds to the American recitation, in which students are called upon to answer questions and invited to ask them, is not very usual, except where only members of the lecturer's own college are present. We should designate such a mode of teaching as a "catechetical lecture" or "informal instruction." It is more frequent in "pass" than in "honour" subjects. The large combined lecture has, as yet, proven less suitable for the more elementary teaching. It should be added that lectures occur, as a rule, twice or three 
times a week, and last nominally one hour, but as many undergraduates have to come from one college to another, most lectures do not begin until about ten minutes after the hour.

This is the formal instruction which has been described. There is another side to instruction at Oxford. The chief part of a college tutor's work consists in hearing and criticising the essays and papers which he prescribes to his pupils. The essay writing is the most characteristic feature of Oxford education. As a rule, every undergraduate reading for an "honours" final school, such as literce humaniores, jurisprudence or modern history, ${ }^{1}$ brings at least one essay to his tutor every week. Lecturers occasionally set papers to those attending the lecture, and most colleges have college examinations at the end of the terms to test the term work.

The instruction, as before stated, is given partially by the University and partially by the colleges. It goes without saying that all the students of Oxford have equal privileges with regard to University instruction. On the contrary the instruction of the colleges is intended primarily for the members of each particular college. In most "honour" subjects, however, the colleges are now combined on a principle of reciprocity, i. e., every college which provides a lecture in any school is entitled to send its men to other lectures in the same school, without any special fee. In some cases a small fee is charged to those coming from another college than that of the lecturer.

The advantages of Oxford education are in a certain measure open to others than students of the University. Some professors' lectures are "public lectures," and anyone who likes may attend. Indeed, cases have been known where professors who deal with subjects that have no examination value have lectured entirely or mainly to a

1 Of course, I am not speaking of subjects such as mathematics, physics, natural science, etc., where the work is necessarily of a different kind. 
non-academical audience. But this is, of course, an abnormal phenomenon. Students of the Oxford Association for the Higher Education of Women obtain leave to attend a large number of professional and college lectures along with the men. They pay a small fee. It is quite exceptional and contrary to custom for any college lecture to be attended by anyone not a member of the University (except in the case of the women students just mentioned, who can go in for most of the same examinations as the men, though the University gives them only a certificate and no degree). Neither the University nor the colleges give any recognition to members of other universities, simply as such. Thus a member of a German or an American university, even if a graduate, can only obtain the privileges of the University of Oxford by fulfilling the same conditions as if he had just come from school. Members of Cambridge and of Trinity College, Dublin, may become members of Oxford on easier terms, and a few English local colleges and Colonial universities are now "affiliated" to Oxford, so that students coming from them may count some portion of their previous academical course. The educational inhospitality of the English universities is on every ground much to be regretted. It is a falling away from the international character of the mediæval universities, and arose out of the peculiarity of the English Reformation, which cut off the Church of England alike from the Catholicism and from the Protestantism of the rest of Europe. In the English universities, ecclesiastical "tests" are now abolished (except for theological professorships and degrees in divinity), but the tradition of exclusiveness survives, though the original reason for it has disappeared.

The academical year consists nominally of four, practically of three terms, viz. : Michaelmas Term, from about the middle of October to the middle of December; Hilary, or Lent Term, from about the middle of January to the middle of March; Easter and Trinity, counting as one term for all educational purposes, from some time in April 
(earlier or later according to the date of Easter) to some time in June. College lectures are given during eight weeks of each term, professional lectures generally for six weeks only. As a rule, at combined college lectures, attendance is ascertained at least occasionally and a report is made from time to time to the various colleges from which undergraduates come. It is less common for professors to ascertain attendance, and the audience fluctuates more. It is the business of the college tutor to advise his pupils what lectures to attend, what books to read, etc., and it is he who also endeavors to secure their regular attendance at lectures, whether his own or those of other lecturers. If necessary, college discipline can be brought to bear upon frequent defaulters, $i . e$, the undergraduate who "cuts" lectures does it at his own risk; needless to say, it is sometimes done.

Every undergraduate, in residence, pays his college each term seven pounds sterling or more, i. e., annually twenty-one pounds sterling or more, as tuition fee. This, as a rule, covers all expense of his tuition, unless he chooses to go to a private "coach" in addition. Whether he attends many or few lectures makes no difference. As a rule, an undergraduate is advised not to have more than about eight lectures to hear each week, exclusive of the time he spends with his tutor with essays, etc., or for informal instruction. But, of course, the number of lectures he attends will vary according to the stage at which he has arrived in his work, the lectures that happen to be available for the term, his need of help, or his power of working by himself, and so on. As to expense, it may be noted that tuition is a small part of the expenses of an Oxford or Cambridge undergraduate. One hundred and fifty pounds sterling per annum may be set down as the minimum at which a fairly careful man, at an average college, can get through his academical terms without depriving himself of many of the social advaniages of the place. At some colleges the average expense would be lower, at others higher. A really able man who has been well 
The Teaching of Political Science at Oxford. 93

taught at school can make pretty sure of obtaining a scholarship, generally of eighty pounds sterling per annum.

As to work done in political science apart from professional and combined college lectures, it is impossible to give any precise information. It may be said that nearly every college tutor who has to do with preparing pupils for the final schools of litere humaniores, modern history, or jurisprudence, is at some time or to some extent engaged in such teaching. Every tutor in these schools is assumed to have some general acquaintance with political and social science, and no undergraduate can read for any of these schools without having the subject brought before him. When it is understood that what in Oxford is called a "classical" education, includes, e. g., political economy (though in most cases not very much of it), the liberal character of our educational system may be estimated. Whether a great University should not likewise do more for the advancement of learning in special studies, is a question that may very well be asked. At present, we have to a very large degree "the defects of our qualities." What is known as the "college system," i.e., the system according to which education is chiefly cared for by the college instead of by the University, has its ardent admirers; but one result of it is that, for many purposes, where there might be one magnificent University, we have twenty small ones existing side by side.

I have annexed a list of the lectures on political and social science, open to all students of the University during the academic year of $1890-1891 .^{1}$

\section{Oxford University.}

\section{G. Ritchie.}

1 For a brief but careful account of many of the most puzzling peculiarities of the two ancient English universities, I would refer the American reacier to Baedeker's Great Britain (pp. 224-227, of $2 \mathrm{~d}$ ed.). I have said nothing about Cambridge, as there are many differences from Oxford, both as to the examination system, and as to the arrangement for tuition. The system of study in Oxford is described in detail in a semi-official publication called The Student's Handbook to the University and Colleges of Oxford, which will be found less unintelligible than the official Examination Statutes; both are published at the Clarendon Press, Oxford. 